\title{
ПРОБЛЕМЫ ОЦЕНКИ ПЕРСОНАЛА ПРИ ВНЕДРЕНИИ КЛИЕНТООРИЕНТИРОВАННОЙ СТРАТЕГИИ
}

\author{
И. Ю. Мельникова, Ю. Н. Соина-Кутищева \\ Новокузнеций филиал-институт государственного образовательного учреждения \\ высшего образования «Кемеровский государственный университет»
}

Поступила в редакцию 29 ноября 2019 г.

\begin{abstract}
Аннотация: на основе теоретических и эмпирических данных проведен анализ характеристик клиентоориентированного персонала, определены уровни ориентации работников на клиента. Проведен анализ методов оценки клиентоориентированности персонала, дано обоснование необходимости формирования комплекса оценочных инструментов, ограничения и результаты их применения.
\end{abstract}

Ключевые слова: клиентоориентированная стратегия, оценка персонала, методь оценки персонала.

Abstract: in the article, the analysis of the characteristics of client-oriented personnel is executed on the basis of theoretical and empirical data. The levels of employee orientation to the client are defined. The analysis of methods for assessing the client-orientation of the staff is carried out. The need to develop a set of assessment tools is justified. The limitations and results of the application of staff assessment methods are also given.

Key words: customer-focused strategy, personnel assessment, personnel assessment methods.

В связи с развитием конкуренции и ростом предложения представление покупателя об отличном сервисе значительно поменялось. Предлагаемый товар остается необходимым, но далеко не достаточным средством завоевания покупателя. В настоящее время составляющими сервиса высокого класса выступают условия и атмосфера приобретения товара, комфортность, удобное месторасположение, а также характеристики взаимодействия покупателя с персоналом организации. Необходимым условием является качественная работа персонала организации, так как именно он является ключевым звеном в формировании лояльности клиента. А для этого необходимо формирование такого коллектива сотрудников, который признает главной ценностью организации клиента и его потребности, т. е. клиентоориентированного персонала, что в свою очередь является важнейшим составляющим элементом набирающей популярность клиентоориентированной стратегии развития фирм.

Стоит разобраться подробнее в том, что же такое клиентоориентированность персонала. Анализируя различные источники, можно выделить тот факт, что авторы дают лишь некоторые характеристики, которыми должен обладать персонал, но не дают точной и полной трактовки данной дефиниции, а также точного и системного описания клиентоори-

(С Мельникова И. Ю., Соина-Кутищева Ю. Н., 2020 ентированного персонала. Сформулируем данное определение, исходя из общей трактовки понятия клиентоориентированной стратегии.

Клиентоориентированная стратегия - это стратегия управления взаимоотношениями с потребителями, позволяющая организации извлекать дополнительную прибыль вследствие глубокого понимания и удовлетворения потребностей клиента в долгосрочной перспективе [1]. Отсюда можно сделать вывод, что клиентоориентированный персонал - это сотрудники организации, которые располагают набором определенных компетенций, реализуют его на практике в соответствующем поведении в ходе выполнения своих должностных обязанностей, способствующие установлению и поддержанию долгосрочных взаимоотношений с потребителями вследствие глубокого понимания и удовлетворения их потребностей. Под компетенциями же понимается совокупность знаний, умений и навыков, а также мотивационных, ценностных характеристик и личных качеств, необходимых для успешного выполнения работы, соответствия должности и стратегическим целям организации [2].

По мнению С. Н. Апенько, основными характеристиками клиентоориентированного персонала выступают:

- знание целевых клиентов организации, их предпочтений, знание существующих стандартов обслуживания, а также особенностей предлагаемых товаров и услуг; 
- умение установить контакт с клиентом, выявить, актуализировать его запросы;

- стремление к максимальному удовлетворению потребностей как постоянного, так и потенциального клиента;

- умение распознать индивидуальные особенности любого клиента;

- соблюдение существующих стандартов обслуживания и идеологических установок организации, направление их на установление и поддержку долгосрочных отношений с клиентом [3].

Авторы выделяют ряд важных качеств сотрудников, необходимых для создания высококачественного сервиса:

- искренность и теплота в отношении к потребителю - люди очень чутко чувствуют фальшь и поддельную доброжелательность;

- эмпатия, умение сочувствовать, умение понимать переживания других людей;

- готовность и желание помогать людям и клиентам в частности;

- оптимистическое, приподнятое настроение - так как обслуживание - дело непростое, важно уметь собраться с мыслями и поддерживать позитивный настрой в общении даже с самым «труднохарактерным» клиентом;

- командный стиль работы - умение сконцентрировать все необходимые ресурсы организации для решения проблемы клиента;

- добросовестность - это широкое понятие, которое включает в себя ответственность, соблюдение рабочей этики, усердие, внимание к деталям. Добросовестный сотрудник гордится своей качественной работой, внимательно относится к ней [4].

Данные характеристики персонал реализует на практике во время осуществления трудовой деятельности, т. е. проявляя клиентоориентированное поведение. Близкой точки зрения придерживается Д. Митчел, выделяя в качестве необходимых такие характеристики персонала, как компетентность и уверенность, оптимизм, мотивация к развитию и росту, порядочность [5].

По итогам проведенных ранее исследований с применением проективных методик [6] сформулированы следующие характеристики эффективной коммуникации с клиентом:

- возможность получать исчерпывающую и достоверную информацию о товаре, его аналогах, способах употребления товара, функциональных возможностях. Респонденты отметили, что для них важна экономия времени при поиске и сборе информации о товаре, и они рассматривают как по- лезность квалифицированное консультирование и помощь в выборе;

- внимание к своим насущным нуждам и помощь в решении проблем (предоставление товара/ услуги, максимально соответствующих специфическим потребностям, доработка концепции продукта и выполнение индивидуальных заказов);

- гарантированное качество и безопасность купленного товара (полученной услуги);

- возможность получить выгодное предложение (информирование об акциях, предоставление скидок и пр.);

- приветливость, терпеливость и доброжелательность, позитивный настрой обслуживающего персонала, искреннее внимание, уважение к нуждам клиента, «теплая, семейная атмосфера»;

- возможность быть «услышанным и понятым», высказать свои пожелания и идеи, претензии;

- проявление «особого отношения» к постоянным клиентам;

- установление «личного контакта», возникновение симпатии;

- доверие в отношениях, уверенность, что продавец не станет «обманывать ради наживы»;

- одобрение сделанного выбора при покупке (эмоциональное и рациональное подкрепление).

Также выделены деструкторы в поведении торгового и обслуживающего персонала (работников фронт-офиса), негативно воспринимаемые клиентами. К ним относятся попытки манипулировать, скрывать или искажать значимую для потребителя информацию, «оценка потребителя по толщине кошелька», отношение к потребителю как к «одноразовому», навязчивость, применение техники агрессивных продаж, невыполнение взятых на себя обязательств. Результаты данных исследований могут быть использованы при построении компетентностных моделей сотрудников, непосредственно контактирующих с клиентами, и в процедурах оценки их деятельности.

М. Н. Шавровская рассматривает оценку персонала, с одной стороны, как способ повышения качества рабочей силы, с другой - как ключевой элемент в системе формирования клиентоориентированности сотрудников наряду с обучением, мотивацией и стимулированием. Автор считает, что грамотно выстроенный процесс деловой оценки служит источником информации об узких местах и проблемах в становлении клиентоориентированной стратегии и позволяет увидеть результат построения отношений с клиентами. Автором подробно рассмотрены критерии оценивания персонала, та- 
кие как сервис, эстетика, вежливость взаимодействия, компетентность взаимодействия, стабильность взаимоотношений [7]. Нами предложен несколько иной подход, рассмотренный ниже. С точки зрения степени влияния параметров поведения сотрудников на конкурентоспособность и финансовую успешность компании нами выделены следующие уровни ориентации на клиента (использованы и доработаны с учетом современных концепций маркетинга материалы диссертационного исследования С. А. Кудрявцева) (рисунок) [8].

Выделение уровней ориентации на клиента может быть использовано для разработки и совершенствования инструментария оценки персонала при внедрении клиентоориентированной стратегии. Данные параметры могут применяться как в ходе оценки сотрудников экспертным путем, так и в процессе оценки с применением стандартных шкал (соответствует требованиям, ниже требований, выше требований и пр.). Также возможно применение параметров при построении количественных шкал с качественным описанием значений шкалы, а в дальнейшем на основе такого дифференцирования поведения сотрудников возможно внедрение системы грейдов.
В практике кадрового менеджмента принято выделять два направления оценки персонала: оценка результативности и оценка потенциала [9]. Оценка результативности деятельности сотрудника в большинстве случаев предполагает количественный подход и выражается в измерении и анализе конкретных показателей за определенный период времени. В рамках данной статьи мы обобщили показатели, применимые, на наш взгляд, для оценки результативности работы сотрудников с клиентами. В данном случае при анализе показателей (например, коэффициент охвата клиентов, коэффициент средней величины заказа) необходимо отслеживать их динамику в долгосрочном периоде, так как изменение на коротком отрезке времени может быть результатом мероприятий по стимулированию сбыта, применения техники агрессивных продаж или влияния других случайных факторов.

Оценка потенциала сотрудников становится актуальной, если мы прогнозируем изменение условий их деятельности (например, карьерный рост, ротация, вменение новых должностных обязанностей и пр.). При этом в практике управления кадрами встречаются случаи, когда разрыв между потенциалом и показателями результативности сотрудника велик. Такая

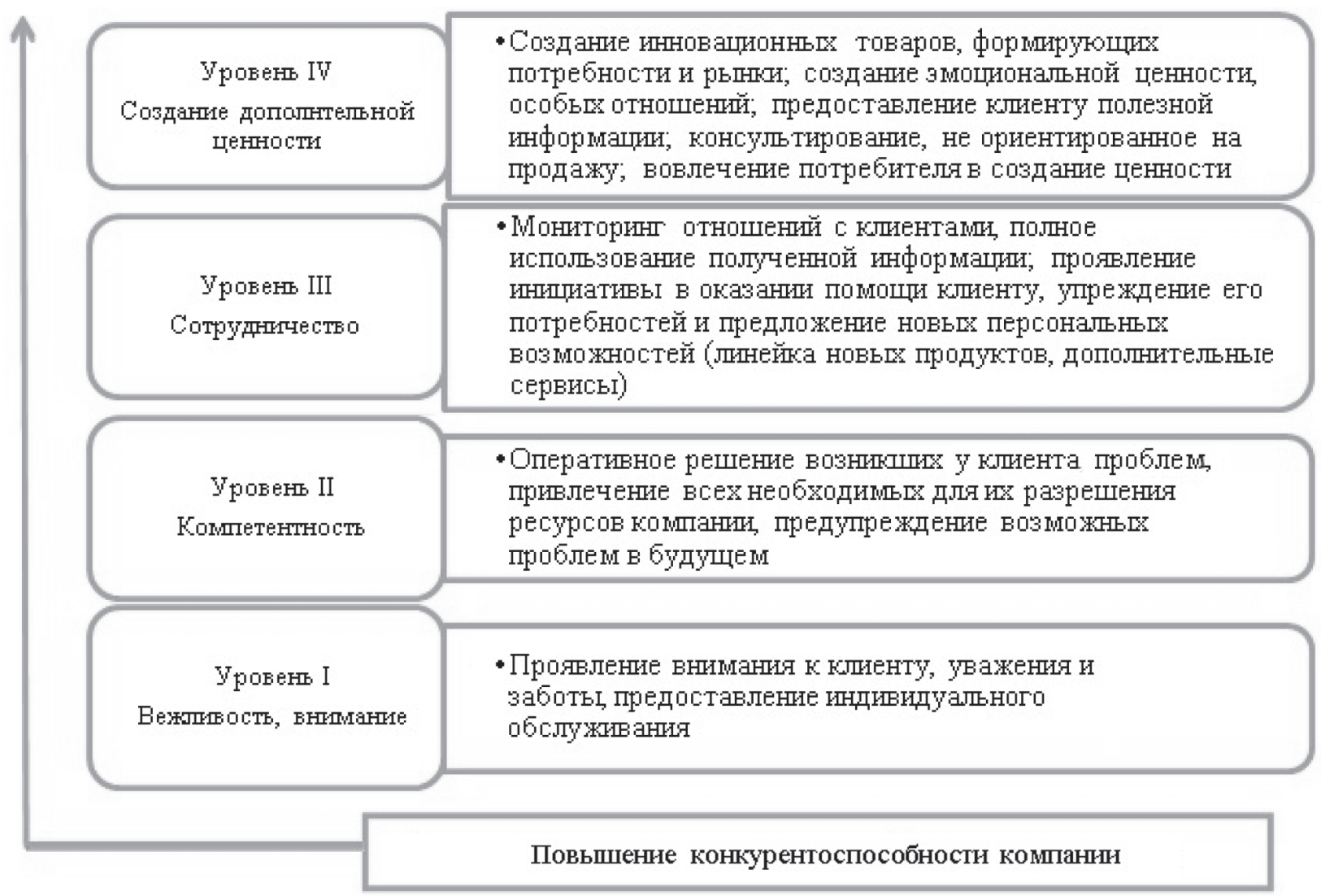

Рисунок. Элементы компетенции «ориентация на клиента» 
ситуация может означать, что работник слабо мотивирован (в том числе из-за отсутствия возможности реализовать свой потенциал). Также данный разрыв может быть связан с ошибками в планировании и неудовлетворительной организацией и координацией работ. И в том, и в другом случае ситуация требует внимания от менеджера и принятия мер.

При оценке клиентоориентированности персонала особую роль играет изучение поведения сотрудников. Именно оценка проявляемого поведения персонала позволяет наиболее полным образом увидеть степень овладения сотрудниками необходимыми компетенциями и их готовность соблюдать стандарты обслуживания. Также изучение поведения сотрудников необходимо вследствие того, что принятая на вооружение клиентоориентированная стратегия не превращается в финансовые результаты моментально. Чтобы завоевать уважение, доверие и любовь потребителя, необходимо время. Оценка поведения сотрудников необходима на первых этапах внедрения стратегии или при выходе на новые рынки (сегменты) и позднее может быть заменена оценкой результативности сотрудников. Еще одна область применения данного направления оценки - это случаи снижения эффективности работы торгового персонала.

Инструментарий кадрового менеджмента обширен, что позволяет при внедрении клиентоориентированной стратегии применять множество различных методов оценки персонала в зависимости от специфики деятельности организации и целей оценки. Нами предложена классификация этих методов (табл. 1).
Следует отметить, что менеджмент современных организаций при оценке персонала обходится в ряде случаев использованием тестирования либо устного опроса на наличие профессиональных знаний. Очевидно, что полученной такими методами информации недостаточно для получения полной картины о ходе организационных изменений. Поэтому необходимо использовать методы оценки, целью которых является анализ поведения сотрудника в смоделированных практических ситуациях, позволяющие оценить адаптивность по отношению к клиенту, инициативность, вариативность мышления. Широко распространена практика наблюдения за поведением работников (в том числе с применением технических средств). При этом следует подчеркнуть важность внешней - т. е. со стороны непосредственного клиента - оценки персонала. Точнее всего ответить на вопрос, насколько компания ориентирована на клиента, может только сам клиент, и исследование удовлетворенности потребителей позволит выяснить наиболее значимые компетенции персонала, а также скорректировать поведение сотрудников при взаимодействии с покупателем [10].

Высока популярность (в особенности в сфере торговли) такого метода оценки, как «тайный покупатель» (mystery shopping research). Однако практическое применение данного метода связано с рядом проблем, а результативность исследования зависит от качества реализации всех его этапов, начиная с планирования и разработки форм для сбора данных. Помимо использования некачественно составленных или позаимствованных (заведомо неадекватных целям

Т а б л и ц а 1

Классификация методов очฺенки персонала при внедрении и реализащчи стратегии ориентации на клиента

\begin{tabular}{|l|l|}
\hline \multicolumn{1}{|c|}{ Критерий классификации } & \multicolumn{1}{|c|}{ Группы методов оценки } \\
\hline Субъект оценки & $\begin{array}{l}\text { - Внутренняя оценка (осуществляется руководителем, аттестационной } \\
\text { комиссией, специалистом по управлению персоналом или экспертом - } \\
\text { работником организации); } \\
\text { - внешняя оценка (осуществлется клиентом или приглашенным спе- } \\
\text { циалистом-экспертом) }\end{array}$ \\
\hline Предмет оценки & $\begin{array}{l}\text { Оценка результативности; } \\
\text { - оценка потенциала; } \\
\text { - оценка поведения }\end{array}$ \\
\hline Тип используемой при оценке инфор- & $\begin{array}{l}\text { - Количественные методы; } \\
\text { мации }\end{array}$ \\
\hline Способ получения / преобразования & - комплексные (комбинированные) методы \\
информации, используемой при оценке & $\begin{array}{l}\text { Прямые методы оценки (оцениваемый параметр непосредственно свя- } \\
\text { зан с деятельностью/поведением работника, может быть измерен/оценен } \\
\text { на основе наблюдения за работой сотрудника или в ходе оценочных про- } \\
\text { цедур или рассчитан на основе объективных данных); } \\
\text { - косвенные методы оценки (оценочные суждения выносятся на основе } \\
\text { анализа показателей, не связанных непосредственно с поведением работ- } \\
\text { ника и его деятельностью) }\end{array}$ \\
\hline
\end{tabular}


исследования) опросных листов или листов наблюдений, имеют место следующие негативные моменты:

составление опросного листа без учета основных ценностей потребителя. Формы сбора данных, как правило, разрабатывают специалисты консалтинговых агентств, ориентируясь при этом на собственные критерии эффективности обслуживания клиентов. Для анализа используемых форм сбора данных мы изучили образцы анкет и рекомендации к их составлению, размещенные на различных информационных pecypcax. Эмпирической базой для анализа являлись материалы, размещенные на официальных сайтах консалтинговых агентств и бизнес-журналов (перечень использованных для анализа источников и ресурсов приведен в табл. 2).

К примеру, в опросных листах часто фигурируют такие оцениваемые параметры, как умение продавца осуществлять дополнительные продажи и кросс-продажи. В фокусе внимания при этом - внутренняя эффективность деятельности торгового персонала (выполнение плана продаж). Однако вызывает сомнение заинтересованность клиента в том, чтобы его стимулировали к покупке на большую сумму? Также представляется спорным использование в качестве оценочного критерия умения продавца ответить на возражения клиента, поскольку в этом случае не учитывается мнение покупателя (его желание вступать в спор, интерес к доводам и аргументам продавца).

При этом не встречается в опросных листах критерий оценки «полезность и актуальность полученной клиентом от продавца информации». Применение таких форм сбора данных означает, что наблюдатель в ходе исследования оценивает поведение персонала с позиции менеджера (руководителя). Что является ценностью для реального клиента и в чем причины его неудовлетворенности - остается за пределами внимания исследователей. М. Н. Шавровская определяет оценку клиентоориентированности персонала как процесс соотнесения существующих знаний, умений, навыков, ценностей, установок, мотивации и поведения персонала с желательными их параметрами по заранее заданным критериям, а также выявления конкретных результатов, к которым опосредованно приводит клиентоориентированность сотрудников [11]. На данном этапе происходит подмена истинной ориентации на клиента на декларируемую, так как «желательные параметры» задаются без учета мнения потребителя. Эти недостатки могут быть

Перечень источников, использованных при анализе форм сбора данньхх при проведении оценки персонала методом «тайный покупатель»

\begin{tabular}{|c|c|c|}
\hline $\begin{array}{l}\text { Наименование ресурса/ } \\
\text { консалтинговой компании }\end{array}$ & Сайт & Ссылка на использованный материал \\
\hline $\begin{array}{l}\text { Маркетинговое агентство } \\
\text { Life-Marketing }\end{array}$ & $\begin{array}{l}\text { http://www.life- } \\
\text { marketing.ru }\end{array}$ & $\begin{array}{l}\text { http://www.life-marketing.ru/life-marketing/primer_anketi_ } \\
\text { tainiy_pokupatel }\end{array}$ \\
\hline $\begin{array}{l}\text { Агентство стратегического } \\
\text { маркетинга Spezia }\end{array}$ & http://asm-spezia.ru & $\begin{array}{l}\text { http://asm-spezia.ru/kopilka-marketologa/texnologiya-tajnyij- } \\
\text { pokupatel-6-osnovnyix-shagov.html }\end{array}$ \\
\hline Бизнес-центр Retail.ru & https://www.retail.ru & https://www.retail.ru/articles/108369/ \\
\hline 4SERVICE GROUP ${ }^{\circledR}$ Россия & $\begin{array}{l}\text { http://4service-group. } \\
\text { com/ru }\end{array}$ & $\begin{array}{l}\text { http://4service-group.com/ru/about/press-about-us/tajnyj- } \\
\text { pokupatel-vse-chto-nuzhno-ob-etom-znat }\end{array}$ \\
\hline $\begin{array}{l}\text { Электронный журнал } \\
\text { Shoes Report }\end{array}$ & $\begin{array}{l}\text { http://www.shoes- } \\
\text { report.ru }\end{array}$ & $\begin{array}{l}\text { http://www.shoes-report.ru/articles/prodazhi/taynyy- } \\
\text { pokupatel-dlya-idealnykh-prodazh/ }\end{array}$ \\
\hline $\begin{array}{l}\text { Петербургская консалтинго- } \\
\text { вая группа }\end{array}$ & $\begin{array}{l}\text { http://www.staff- } \\
\text { recruit.ru }\end{array}$ & $\begin{array}{l}\text { http://www.staff-recruit.ru/anketa_proverki_obslujivaniya_v__ } \\
\text { restorane }\end{array}$ \\
\hline $\begin{array}{l}\text { Консалтинговое агентство } \\
\text { «СкаутМаркетин» }\end{array}$ & http://www.scoutmr.ru & $\begin{array}{l}\text { http://www.scoutmr.ru/docs/tajnyj_pokupatel/anketa_ocenki_ } \\
\text { kachestva_obsluzhivanija_avtosalona.pdf }\end{array}$ \\
\hline Портал LiveInternet & $\begin{array}{l}\text { https://www. } \\
\text { liveinternet.ru/corp/ } \\
\text { about.html }\end{array}$ & $\begin{array}{l}\text { https://www.liveinternet.ru/users/klub_taynyih_pokupatelei/ } \\
\text { post265860968/ }\end{array}$ \\
\hline Бизнес-журнал «Жажда» & https://zhazhda.biz & https://zhazhda.biz/base/anketa-tajnogo-pokupatelya \\
\hline $\begin{array}{l}\text { Электронный журнал } \\
\text { «Шопоголики» }\end{array}$ & $\begin{array}{l}\text { http://shopogoliki. } \\
\text { by/o-zhurnale\# }\end{array}$ & $\begin{array}{l}\text { http://shopogoliki.by/shopogid/reviziya/anketa-dlya-taynogo- } \\
\text { pokupatelya\# }\end{array}$ \\
\hline $\begin{array}{l}\text { Агентство «Тайный поку- } \\
\text { патель» }\end{array}$ & http://amshopping.ru & $\begin{array}{l}\text { http://amshopping.ru/index.php?page=anketa_tainogo_ } \\
\text { pokupatelya }\end{array}$ \\
\hline $\begin{array}{l}\text { «Актион управление и фи- } \\
\text { нансы». Журнал Коммерче- } \\
\text { ский директор }\end{array}$ & https://www.kom-dir.ru & $\begin{array}{l}\text { https://www.kom-dir.ru/article/1246-qqq-16-m5-24-05-2016- } \\
\text { anketa-taynogo-pokupatelya }\end{array}$ \\
\hline
\end{tabular}


устранены, если видоизменить процедуру сбора данных, дополнив заполнение наблюдателями стандартизированных форм последующей беседой с ними. Цель такой беседы - сбор дополнительной информации качественного типа (какое в целом сложилось впечатление от контакта, вызвали ли действия продавца неудовольствие / раздражение или замешательство клиента, какие это были действия и почему они вызвали негативную реакцию, имели ли место другие раздражающие факторы, возникло ли желание вновь прийти в эту компанию, хочет ли клиент, чтобы его обслуживал тот же продавец, и пр.). В ряде случаев для проведения беседы целесообразно применение техники зондирующих вопросов.

Опираясь на результаты проведенного анализа, можно сделать вывод о наличии ряда серьезных проблем в организации, проведении и интерпретации результатов оценки клиентоориентированности персонала на основе использования метода «тайный покупатель». К таким проблемам в первую очередь следует отнести:

- низкий уровень квалификации агентов (тайных покупателей), непонимание целей исследова- ния, неспособность выделить и зафиксировать значимую информацию. По оценкам экспертов, к выполнению данной работы часто привлекают случайных исполнителей.

- недостаточный уровень заинтересованности агентов в сборе качественной и пригодной для анализа информации, формальный подход к работе, что в том числе связано с низким уровнем оплаты за выполненную работу;

- непрофессиональный подход к интерпретации и использованию полученных данных. Анализ результатов оценки, как правило, сводится к поиску нарушений в поведении сотрудников и фактов несоблюдения инструкций и регламентов. Полученную информацию используют для обоснования мер негативного стимулирования, в то время как положительный эффект (способность и желание исправлять ошибки) может быть достигнут только при построении программ обучения (или коучинг-сопровождения) с учетом выявленных проблем.

Таким образом, возможные методы оценки клиентоориентированности персонала представим в табл. 3 [12-16].

Т а б ли ц а 3

Методы оценки клиентоориентированности персонала

\begin{tabular}{|c|c|c|}
\hline $\begin{array}{c}\text { Метод оценки клиентоориенти- } \\
\text { рованности персонала }\end{array}$ & Описание метода & $\begin{array}{c}\text { Оцениваемые } \\
\text { показатели/параметры }\end{array}$ \\
\hline 1 & 2 & 3 \\
\hline \multicolumn{3}{|c|}{ Качественные методы } \\
\hline \multicolumn{3}{|c|}{ Внутренняя оценка } \\
\hline $\begin{array}{l}\text { Тестирование } \\
\text { (профессиональное) }\end{array}$ & $\begin{array}{l}\text { Использование тестовых заданий для оцен- } \\
\text { ки профессиональной компетентности со- } \\
\text { трудника }\end{array}$ & $\begin{array}{l}\text { Знание стандартов обслужива- } \\
\text { ния, профессиональных знаний } \\
\text { (например, техники продаж, } \\
\text { ассортимента предлагаемых } \\
\text { товаров, товаров-конкурентов, } \\
\text { потребительских сегментов) }\end{array}$ \\
\hline $\begin{array}{l}\text { Тестирование } \\
\text { (психологическое) }\end{array}$ & $\begin{array}{l}\text { Применение тестовых методик с учетом } \\
\text { специфики деятельности сотрудников }\end{array}$ & $\begin{array}{l}\text { Психологические качества, } \\
\text { свойства личности важные при } \\
\text { обслуживании клиента (эмпа- } \\
\text { тия, оптимизм, готовность к } \\
\text { сотрудничеству и пр.) }\end{array}$ \\
\hline Кейс-метод & $\begin{array}{l}\text { Задание практической ситуации, основанной } \\
\text { на реальном фактическом материале или } \\
\text { приближенной к реальной ситуации, требу- } \\
\text { ющей исследования и предложения возмож- } \\
\text { ных решений и выбора лучшего из них }\end{array}$ & $\begin{array}{l}\text { Модели поведения сотрудников, } \\
\text { ценностные и мотивационные } \\
\text { установки, знание специфики } \\
\text { бизнеса и товаров-конкурентов, } \\
\text { а также деловые и личностные } \\
\text { качества (коммуникабельность, } \\
\text { способность быстро анализиро- } \\
\text { вать информацию, мобильность, } \\
\text { вариативность мышления и т. д.) } \\
\end{array}$ \\
\hline $\begin{array}{l}\text { Метод альтернативных } \\
\text { характеристик }\end{array}$ & $\begin{array}{l}\text { Оценка сотрудника (заполнение оценочных } \\
\text { форм) руководителем или экспертом с точки } \\
\text { зрения наличия или отсутствия рассматрива- } \\
\text { емого показателя оценки }\end{array}$ & $\begin{array}{l}\text { Деловые и личностные качества } \\
\text { (коммуникабельность, доброже- } \\
\text { лательность, способность быстро } \\
\text { анализировать информацию и пр.) }\end{array}$ \\
\hline
\end{tabular}


Проблемы оченки персонала при внедрении клиентоориентированной стратегии

Продолжени е табл. 3

\begin{tabular}{|c|c|c|}
\hline 1 & 2 & 3 \\
\hline $\begin{array}{l}\text { Шкала наблюдения за поведе- } \\
\text { нием }\end{array}$ & $\begin{array}{l}\text { В ходе сплошного или моментного наблю- } \\
\text { дения осуществляется фиксация поступков. } \\
\text { Для определения поведения работника в } \\
\text { целом оценщик на шкале фиксирует коли- } \\
\text { чество случаев, когда работник вел себя тем } \\
\text { или иным образом }\end{array}$ & $\begin{array}{l}\text { Поведенческие модели, деловые } \\
\text { и личностные качества (комму- } \\
\text { никабельность, доброжелатель- } \\
\text { ность, способность быстро ана- } \\
\text { лизировать информацию и пр.) }\end{array}$ \\
\hline $\begin{array}{l}\text { Поведенческие интервью } \\
\text { (методики STAR и PARLA) }\end{array}$ & $\begin{array}{l}\text { Интервью с применением зондирующих } \\
\text { техник о реальных проблемах, которые кан- } \\
\text { дидат решал в своей работе. Метод выявля- } \\
\text { ет то, как кандидат справляется с опреде- } \\
\text { лёнными рабочими задачами и какие уроки } \\
\text { извлекает из полученного опыта }\end{array}$ & $\begin{array}{l}\text { Поведенческие модели, спо- } \\
\text { собность к анализу проблем, } \\
\text { постановке целей, достижению } \\
\text { результата }\end{array}$ \\
\hline Репертуарные решетки & $\begin{array}{l}\text { Решетка (РР) представляет собой матрицу, } \\
\text { определенным образом организованную, } \\
\text { которая заполняется либо самим испытуе- } \\
\text { мым, либо экспериментатором в процессе } \\
\text { структурированного интервью. В рамках } \\
\text { анализа работы менеджера просят обрисо- } \\
\text { вать те конструкты, ту систему понятий, } \\
\text { с помощью которых он отличает хороших } \\
\text { исполнителей от тех, кто менее успешен в } \\
\text { работе. Метод не предлагает респондентам } \\
\text { заранее установленные рамки для описа- } \\
\text { ния этих характеристик, а позволяет им } \\
\text { привлекать свой собственный опыт, чтобы } \\
\text { определить существенные особенности, } \\
\text { влияющие на выполнение работы }\end{array}$ & $\begin{array}{l}\text { Поведенческие модели, деловые } \\
\text { и личностные качества; инфор- } \\
\text { мация о неочевидных критериях } \\
\text { эффективности работы }\end{array}$ \\
\hline $\begin{array}{l}\text { Шкала BARS (Behaviorally } \\
\text { Anchored Rating Scale) }\end{array}$ & $\begin{array}{l}\text { Поведенческие рейтинговые шкалы опи- } \\
\text { сывают различные варианты поведения в } \\
\text { ситуации от желательного и ожидаемого до } \\
\text { крайне нежелательного. Составляются на } \\
\text { основе критических ситуаций, характерных } \\
\text { для данного вида деятельности. В анкете } \\
\text { рейтинга содержится обычно от шести до } \\
\text { десяти решающих ситуаций с описанием } \\
\text { поведения. Лицо, проводящее оценку, отме- } \\
\text { чает то описание, которое в большей степе- } \\
\text { ни соответствует поведению сотрудника в } \\
\text { рабочей ситуации. Тип поведения соотно- } \\
\text { сится с баллом по шкале }\end{array}$ & $\begin{array}{l}\text { Поведенческие модели, дело- } \\
\text { вые и личностные качества }\end{array}$ \\
\hline $\begin{array}{l}\text { Оценка на основе } \\
\text { компетентностной модели }\end{array}$ & $\begin{array}{l}\text { Руководителем или экспертом осуществля- } \\
\text { ется оценка разрыва между необходимым и } \\
\text { существующим уровнем компетентности }\end{array}$ & $\begin{array}{l}\text { Поведенческие модели, дело- } \\
\text { вые и личностные качества } \\
\text { (коммуникабельность, добро- } \\
\text { желательность, способность } \\
\text { быстро анализировать инфор- } \\
\text { мацию и пр.) }\end{array}$ \\
\hline $\begin{array}{l}\text { Построение } \\
\text { графического профиля }\end{array}$ & $\begin{array}{l}\text { Отражение оценщиком (руководителем } \\
\text { или экспертом) уровня каждого из ка- } \\
\text { честв работника (личностных, деловых), } \\
\text { оцениваемых в баллах, в виде точек на } \\
\text { графической шкале и построение профиля } \\
\text { сотрудника }\end{array}$ & $\begin{array}{l}\text { Деловые и личностные каче- } \\
\text { ства }\end{array}$ \\
\hline Ролевые игры & $\begin{array}{l}\text { Моделирование рабочей ситуации, в кото- } \\
\text { рой каждому из оцениваемых работников } \\
\text { назначается роль, с дальнейшим воспро- } \\
\text { изведением ими поведенческих моделей, } \\
\text { успешных для их профессиональной дея- } \\
\text { тельности }\end{array}$ & $\begin{array}{l}\text { Оценка мотивов, профессио- } \\
\text { нальных поведенческих моде- } \\
\text { лей, проявления профессио- } \\
\text { нальных компетенций }\end{array}$ \\
\hline
\end{tabular}


Продолжени е табл. 3

\begin{tabular}{|c|c|c|}
\hline 1 & 2 & 3 \\
\hline Проективное интервью & $\begin{array}{l}\text { Использование в глубинном интервью вопро- } \\
\text { сов, предполагающих оценку кандидатом не } \\
\text { себя, а других людей. Особенность метода в } \\
\text { том, что, объясняя поведение или действия } \\
\text { других людей, человек склонен переносить } \\
\text { свой жизненный опыт и ценностные установ- } \\
\text { ки на интерпретацию действий других }\end{array}$ & $\begin{array}{l}\text { Ценностные (честность, лояль- } \\
\text { ность) и мотивационные уста- } \\
\text { новки личности, особенности } \\
\text { характера }\end{array}$ \\
\hline \multicolumn{3}{|c|}{ Внешняя оценка } \\
\hline Анкетирование & $\begin{array}{l}\text { Опрос клиентов с использованием заранее } \\
\text { сформулированного бланка вопросов - анкеты. } \\
\text { Позволяет выяснить общее отношение к брен- } \\
\text { ду, к важным для клиента характеристикам } \\
\text { обслуживающего персонала, уровню обслужи- } \\
\text { вания, ассортименту и так далее. Проведение } \\
\text { допустимо с помощью разнообразных каналов } \\
\text { коммуникаций (телефона, электронной почты, } \\
\text { печатных бланков в торговом зале) }\end{array}$ & $\begin{array}{l}\text { Лояльность клиента, а также } \\
\text { оценка поведения сотрудника } \\
\text { в процессе обслуживания, } \\
\text { оценка в целом позициониро- } \\
\text { вания компании и комплекса } \\
\text { маркетинга }\end{array}$ \\
\hline Тайный покупатель & $\begin{array}{l}\text { Оценка качества работы персонала с помощью } \\
\text { обученного «покупателя», который оценива- } \\
\text { ет уровень обслуживания после контакта с } \\
\text { продавцом. Эффективность метода в том, что } \\
\text { покупку совершает незаинтересованное лицо, } \\
\text { которое сможет дать объективную оценку }\end{array}$ & $\begin{array}{l}\text { Профессиональные и лич- } \\
\text { ностные качества персонала, } \\
\text { ориентация на клиента и его } \\
\text { потребности }\end{array}$ \\
\hline Ассесмент-центр & $\begin{array}{l}\text { Проведение оценки потенциала сотрудников } \\
\text { посредством моделирующих упражнений } \\
\text { (деловых игр). В ходе оценки эксперты на- } \\
\text { блюдают за демонстрируемым поведением } \\
\text { работника с дальнейшим обсуждением полу- } \\
\text { ченных результатов }\end{array}$ & $\begin{array}{l}\text { Оценка мотивов, профессио- } \\
\text { нальных поведенческих моде- } \\
\text { лей, проявления профессиональ- } \\
\text { ных компетенций, соответствие } \\
\text { требованиям должности, нали- } \\
\text { чие потенциала к занятию руко- } \\
\text { водящих должностей }\end{array}$ \\
\hline \multicolumn{3}{|c|}{ Количественные методы } \\
\hline $\begin{array}{l}\text { Абсолютные показатели } \\
\text { по результатам работы }\end{array}$ & $\begin{array}{l}\text { Оценка количественных результатов работы } \\
\text { как каждого сотрудника, так и подразделе- } \\
\text { ния в целом. Используются такие показа- } \\
\text { тели, как объем реализованных товаров и } \\
\text { услуг, количество привлеченных клиентов, } \\
\text { количество вторично обратившихся клиен- } \\
\text { тов, количество жалоб и благодарностей, } \\
\text { поступивших от покупателей }\end{array}$ & \multirow[t]{4}{*}{$\begin{array}{l}\text { Оценка динамики изменения } \\
\text { показателей при выявлении } \\
\text { тенденции ухудшения, выясне- } \\
\text { ние конкретных причин: субъ- } \\
\text { ективного или объективного } \\
\text { характера }\end{array}$} \\
\hline Коэффициент утраты клиентов & $\begin{array}{l}\mathrm{K}_{\text {ок }}=\frac{\text { Количество клиентов, совершивших покупку }}{\text { Общее число клиентов }} \\
\text { отражает эффективность работы персонала, } \\
\text { их способности к стимулированию } \\
\text { совершения покупки потребителем; } \\
\mathrm{K}_{\text {ук }}=1-\mathrm{K}_{\text {ок }}-\text { обратный показатель, отра- } \\
\text { жающий долю клиентов, отказавшихся от } \\
\text { совершения покупки; }\end{array}$ & \\
\hline $\begin{array}{l}\text { Коэффициент привлечения но- } \\
\text { вых клиентов }\end{array}$ & $\begin{array}{l}\mathrm{K}_{\text {нк }}=\frac{\text { Количество новых клиентов }}{\text { Общее число обслуженных клиентов }} \\
\text { отражает способность продавца установить } \\
\text { контакт с потенциальным покупателем и } \\
\text { превратить его в активного клиента; } \\
\mathrm{K}_{\text {вок }}=1-\mathrm{K}_{\text {нк }} \text { позволяет оценить } \\
\text { приверженность клиентов к компании; }\end{array}$ & \\
\hline $\begin{array}{l}\text { Коэффициент средней величи- } \\
\text { ны заказа }\end{array}$ & $\begin{array}{l}\mathrm{K}_{\mathrm{c3}}=\frac{\text { Объем продаж в денежном выражении }}{\text { Общее число заказов }}- \\
\text { способность продавца обеспечить план } \\
\text { объема продаж, стимулировать потребителя } \\
\text { к приобретению дополнительных товаров }\end{array}$ & \\
\hline
\end{tabular}


Проблемь оченки персонала при внедрении клиентоориентированной стратегии

\begin{tabular}{|c|c|c|}
\hline & & О кон ч ан и е т а бл. 3 \\
\hline 1 & 2 & 3 \\
\hline $\begin{array}{l}\text { MBO (Management by } \\
\text { Objectives) }\end{array}$ & $\begin{array}{l}\text { Сравнение плановых ключевых показателей } \\
\text { деятельности с фактическими. Оценка ре- } \\
\text { зультатов проводится совместно руководи- } \\
\text { телем и работником на основе индивидуаль- } \\
\text { ных стандартов реализации целей }\end{array}$ & $\begin{array}{l}\text { Оценка динамики изменения } \\
\text { показателей при выявлении } \\
\text { тенденции ухудшения, выяс- } \\
\text { нение конкретных причин: } \\
\text { субъективного или объектив- } \\
\text { ного характера }\end{array}$ \\
\hline $\begin{array}{l}\text { Оценка на основе количествен- } \\
\text { ных шкал с качественным опи- } \\
\text { санием значений шкалы }\end{array}$ & $\begin{array}{l}\text { Оценивание конкретного показателя оцен- } \\
\text { ки на основе шкалы. При разработке шка- } \\
\text { лы ее числовые значения интерпретируют- } \\
\text { ся подробным описанием образа действий, } \\
\text { соответствующего данному числовому } \\
\text { значению. Оценка осуществляется руково- } \\
\text { дителем или экспертом }\end{array}$ & $\begin{array}{l}\text { Профессиональные и лич- } \\
\text { ностные качества персонала, } \\
\text { ориентация на клиента и его } \\
\text { потребности }\end{array}$ \\
\hline \multicolumn{3}{|c|}{ Комплексные методы } \\
\hline Performance management (PM) & $\begin{array}{l}\text { Суть метода заключается в сотрудничестве } \\
\text { менеджера и подчиненного при планирова- } \\
\text { нии деятельности и в ходе оценки резуль- } \\
\text { татов. } \\
\text { Основными этапами РМ являются: } \\
\text { - разработка стандартов эффективности и } \\
\text { КРІ (ключевых показателей эффективности); } \\
\text { - постановка задач на основе КРІ; } \\
\text { - оценка выполнения КРІ; } \\
\text { - оценка и моделирование компетенций, не- } \\
\text { обходимых для решения профессиональных } \\
\text { задач. } \\
\text { Оцениваются результаты работы по задачам } \\
\text { и компетенциям, выявляются области разви- } \\
\text { тия и составляются планы обучения сотруд- } \\
\text { ника и развития его карьеры }\end{array}$ & $\begin{array}{l}\text { Оценка результативности, ме- } \\
\text { тодов выполнения поставлен- } \\
\text { ных целей, мотивов, профес- } \\
\text { сиональных поведенческих } \\
\text { моделей, проявления профес- } \\
\text { сиональных компетенций, } \\
\text { выявление областей развития } \\
\text { сотрудника }\end{array}$ \\
\hline Методика «360 градусов» & $\begin{array}{l}\text { Сбор информации об оцениваемом работ- } \\
\text { нике от взаимодействующих с ним лиц с } \\
\text { последующей обратной связью. В основе } \\
\text { метода - «круговая» оценка сотрудника } \\
\text { руководителем, его коллегами, подчинен- } \\
\text { ными, клиентами, а также самооценка, что } \\
\text { позволяет получить объективную оценку } \\
\text { работника сотрудниками разных уровней } \\
\text { организационной структуры компании }\end{array}$ & \multirow[t]{2}{*}{$\begin{array}{l}\text { Лояльность работника к ком- } \\
\text { пании, оценка поведения, } \\
\text { ориентация на клиентов, в } \\
\text { том числе соблюдение регла- } \\
\text { ментов и стандартов. Удовлет- } \\
\text { воренность потребителей и } \\
\text { партнеров }\end{array}$} \\
\hline Методика «540 градусов» & $\begin{array}{l}\text { Разновидность предыдущего метода, пред- } \\
\text { полагается добавление еще двух направле- } \\
\text { ний оценки: оценки со стороны клиентов и } \\
\text { партнеров }\end{array}$ & \\
\hline Воронка продаж & $\begin{array}{l}\text { Инструмент управления процессом про- } \\
\text { даж, а также анализа эффективности } \\
\text { работы персонала. Отражает весь цикл } \\
\text { продажи, начиная с холодного звонка и за- } \\
\text { канчивая заключением сделки. Комплекс- } \\
\text { ный инструмент, позволяющий оценить } \\
\text { не только эффективность используемых } \\
\text { маркетинговых инструментов для стиму- } \\
\text { лирования продаж, но и результативность } \\
\text { менеджеров, определить, на каком этапе } \\
\text { продажи отсеивается наибольшее число } \\
\text { потенциальных покупателей, а также опре- } \\
\text { делить эффективность каждого уровня во- } \\
\text { ронки (конверсия) }\end{array}$ & $\begin{array}{l}\text { Оценка эффективности каж- } \\
\text { дого этапа продаж в дина- } \\
\text { мике, эффективность работы } \\
\text { персонала (средняя продол- } \\
\text { жительность переговоров с } \\
\text { клиентом, отношение количе- } \\
\text { ства потенциальных клиентов } \\
\text { к реальным, доля успешных } \\
\text { продаж и динамика продаж, } \\
\text { конверсия каждого этапа } \\
\text { (доля лидов, т. е. клиентов, } \\
\text { готовых к переходу на следу- } \\
\text { ющий этап продаж) }\end{array}$ \\
\hline
\end{tabular}


Косвенные методы оценки могут быть применены в условиях дефицита времени и финансовых средств для проведения полноценной процедуры оценки персонала, поскольку на основании таких данных можно получить лишь обобщенные данные о системном управлении клиентоориентированностью и конкурентоспособностью, а полученная негативная информация требует дальнейшего анализа и не может трактоваться однозначно, так как может быть следствием неадекватности других элементов. Используемые в этом случае показатели можно разделить на две группы (табл. 4).

Для развития клиентоориентированности сотрудников необходимо проводить постоянную оценку степени развитости знаний и умений сотрудников, а также их поведения, которая позволит правильно составить программы обучения и мотивации сотрудников, а также корректировать и совершенствовать существующие стандарты работы. Поскольку одним из основных этапов внедрения клиентоориентированного подхода является разработка и реализация программы обучения персонала, результативность данного процесса будет во многом зависеть от всесторонней и объективной оценки работы персонала [17]. Качественные методы оценки позволят изучить потенциал сотрудников, их личные и деловые качества, а также особенности их поведения при контакте с клиентом, оказывающие влияние на эффективность работы, причем такую оценку можно получить и от непосредственного руководителя сотрудника, и со стороны внешнего клиента. Использование количественных методов даст возможность наглядно отобразить эффективность работы как персонала в целом, так и отдельных сотрудников, проследить динамику изменения результатов работы, чтобы в дальнейшем корректировать негативные факторы. Комплексные же методы позволят получить еще более всестороннюю оценку работы сотрудников со стороны внутренних клиентов, а также в целом отразить качество и согласованность всех элементов клиентоориентированной стратегии.

Т а б л и ц а 4

Показатели, используемые для косвенной оценки клиентоориентированности персонала

\begin{tabular}{|l|l|}
\hline \multicolumn{1}{|c|}{$\begin{array}{c}\text { Показатели, характеризующие коммерческую } \\
\text { эффективность работы с клиентами }\end{array}$} & \multicolumn{1}{|c|}{$\begin{array}{l}\text { Показатели, характеризующие отношение } \\
\text { клиентов к компании, бренду, продукции }\end{array}$} \\
\hline - Стоимость привлечения клиентов; & - Индекс числа клиентов, имеющих статус «постоянный»; \\
- прибыльность клиента; & - доля сохранённых постоянных клиентов в отчетном году; \\
- ценность жизненного цикла клиента; & - количество решенных проблем клиентов; \\
- доля повторных продаж; & - количество полученных предложений от клиентов; \\
- стоимость бренда & - доля внедренных предложений клиентов в деятельность \\
& компании; \\
& - уровень вовлеченности потребителей; \\
& - индекс надежности, уверенности в покупателях; \\
& - индекс клиентских усилий; \\
& - индекс удовлетворенности клиентов; \\
& - число участников акций, викторин, конкурсов; \\
\hline
\end{tabular}

\section{ЛИТЕРАТУРА}

1. Садовская М. Н. Клиентоориентированный подход в современных системах управления / М. Н. Садовская // Информационные технологии и системы 2012 (ИТС 2012) : материалы Междунар. науч. конф., БГУИР, Минск, Беларусь, 24 октября 2012 г.-Минск : БГУИР, 2012. - С. 90-91.

2. Чуланова О. Л. Методология исследования компетенций персонала организаций : монография / О. Л. Чуланова. - М. : ИНФРА - М, 2015. - 120 с.

3. Апенько С. Н. Методологические основы оценки клиентоориентированности персонала организаций / С. Н. Апенько // Вестник Омского университета. - № 1. 2010. - C. 72-74.
4. Ингильери Л. Выдающийся сервис, отличная прибыль / Л. Ингильери, М. Соломон. - М. : Манн, Иванов и Фербер, 2013. - 224 с.

5. Митчелл Д. Путь к сердцу клиента : пер. с англ. / Д. Митчелл. - СПб. : Питер, 2006. - 224 с.

6. Хуснулина А. Р. Исследование внешней и внутренней клиентоориентированности организаций / А. Р. Хуснулина, И. Ю. Мельникова // Актуальные проблемы экономики и управления в XXI веке : сб. науч. статей, 29-31 марта 2017 г. / Сиб. гос. индустр. ун-т. - Новокузнецк, 2017. - Ч. 1. - С. 57-62.

7. Шавровская М. Н. Теоретические основы формирования и оценки клиентоориентированности персона- 
ла / М. Н. Шавровская // Дискуссия. - 2011. - № 9 (17). C. 62-66.

8. Кудрявцев С. А. Формирование клиентоориентированной стратегии развития кредитной предпринимательской структуры : автореф. дис. ... канд. экон. наук : 08.00.05 / Сергей Алексеевич Кудрявцев. - СПб., 2015. - 17 с.

9. Джинчарадзе Г. Р. Методические аспекты организации процедуры оценки персонала / Г. Р. Джинчарадзе // Инженерный вестник Дона. - 2012. - № 2. - С. 341-342.

10. Харский К. Клиентоориентированность как она есть / К. Харский // Управление сбытом. - № 3. - 2007. C. 34 .

11. Шавровская М. Н. Клиентоориентированность персонала : формирование и оценка : автореф. дис. ... канд. экон. наук : 08.00.05 / Марина Николаевна Шавровская. - Омск, 2011.

12. Круг Э. А. Оценка качества торгового обслуживания клиентов на примере торгового предприятия /

Новокузнеикий филиал-институт государственного образовательного учреждения высшего образования «Кемеровский государственный университет»

Мельникова И. Ю., кандидат экономических наук, доиент

E-mail: iris100@yandex.ru

Соина-Кутищчева Ю. Н., кандидат экономических наук, доиент

E-mail:julinsk@yandex.ru
Э. А. Круг // Перспективы науки и образования. - № 2. 2013. - C. 85-94.

13. Олейник K. Все об управлении продажами / К. Олейник, С. Иванова, Д. Болдогоев. - М. : АЛЬПИНА ПАБЛИШЕР, 2014. - 336 с.

14. Оценка торгового персонала. - URL: http://hrliga. com/index.php id $=595 \&$ module $=$ profession \&op $=$ view

15. Погодина Г. Оценка методом 360 градусов / Г. Погодина // Справочник по управлению персоналом. - № 3. -2009 . - С. 12-15.

16. Петров К. Управление отделом продаж / К. Петров. - М. : Вильямс, 2011. - 336 с.

17. Мельникова И. Ю. О роли «ведущих пользователей» в разработке продуктовых инноваций / И. Ю. Мельникова // Проблемы внедрения результатов инновационных разработок : сб. статей Междунар. науч.-практ. конф. (25 ноября 2015 г., г. Пермь). - 2015.- С. 163-165.

Novokuznetsk Institute-branch of «Kemerovo State University»

Melnikova I. Yu., Candidate of Economic Sciences, Associate Professor

E-mail: iris100@yandex.ru

Soina-Kutisheva Yu. N., Candidate of Economic Sciences, Associate Professor

E-mail: julinsk@yandex.ru 